\title{
Blood cholesterol and apolipoprotein B levels in relation to intakes of animal and plant proteins in US adults
}

\author{
Ellen Smit ${ }^{1}$, F. Javier Nieto ${ }^{1}$ and Carlos J. Crespo ${ }^{2}$ \\ ${ }^{1}$ Department of Epidemiology, Johns Hopkins University, 615 N Wolfe Street, Baltimore, MD 21205, USA \\ ${ }^{2}$ Department of Health and Fitness, American University, Washington DC, USA
}

(Received 19 October 1998 - Revised 23 March 1999 - Accepted 11 May 1999)

\begin{abstract}
Few studies have examined the association between specific sources of protein and blood lipids in a national sample of adults. We examined this relationship in a sample of adults 20 years and older who participated in phase 1 (1988-91) of the Third National Health and Nutrition Examination Survey, a representative sample of the United States non-institutionalized population. After excluding those participants who reported having been told they had high blood cholesterol concentrations, the final sample size was 6228. Mean intakes of different sources of proteins, as a percentage of total protein, were compared in quartiles of blood lipids. Intakes were adjusted for age, sex and race. Additional adjustments were made for other dietary variables, recall day, BMI, smoking, and income. We observed a lower percentage meat, fish and poultry (MFP) protein intake, including a lower percentage of beef and pork protein, among persons in the lowest quartile of serum total cholesterol and apolipoprotein B (ApoB) concentrations than among persons in the higher quartiles. The percentage of plant protein intake was higher in the lowest quartile than in the highest quartile of serum cholesterol. We also observed a higher percentage of fruit protein intake with lower serum cholesterol and ApoB concentrations. We conclude that in this cross-sectional sample, consumption of MFP proteins was consistently higher among persons with higher cholesterol concentrations while consumption of plant proteins was consistently higher among persons with lower cholesterol concentrations. Our findings support the importance of assessing intake of specific protein sources, especially in studies that address dietary intake in relation to blood lipids.
\end{abstract}

Dietary protein: Blood cholesterol: Apolipoprotein B: Epidemiology

The role of type of dietary protein, such as animal and plant proteins, in influencing blood lipids and hence the risk of cardiovascular disease has received little attention in epidemiological studies. Yet the first indication that dietary animal proteins such as those found in milk, eggs and meat are hypercholesterolaemic came as early as 1909 from Ignatowski (1908). He found that adult rabbits fed on a diet containing cholesterol and animal protein developed atherosclerosis. Early in the 1940s animal proteins were shown to have a hypercholesterolaemic effect, independent of dietary cholesterol and fat, whereas plant proteins led to a hypocholesterolaemic effect (Meeker \& Kesten, 1940, 1941). Since that time, many investigators have shown that the type of dietary protein influences lipid metabolism in animals (Carroll, 1978; Beynen \& West, 1987; Kritchevsky et al. 1987) as well as in clinical studies of human subjects (Sirtori et al. 1977; Jacques et al. 1992; Potter et al. 1993; Bakhit et al. 1994; Anderson et al. 1995; Jenkins et al. 1997).
Although population studies on the effect of type of protein on lipids are scarce, one ecological study of thirty countries showed a positive correlation between intake of animal protein and CHD in men aged 55-59 years and a negative correlation with plant protein (Conner \& Conner, 1972). Campbell et al. (1990) and Campbell \& Chen (1994) in a cross-sectional survey in China, found a positive association between serum cholesterol and apolipoprotein B (ApoB) levels and intakes of meat and animal protein, whereas intakes of legumes and plant protein were inversely associated.

In a study of a population of 27529 Seventh-Day Adventists, the relative risk for CHD increased with increasing frequency of meat consumption (Snowdon, 1988). A crosssectional study compared dietary intakes of a group of 167 African American vegetarians (no consumption of animal flesh), semi-vegetarians (one to three servings of animal flesh per week), and non-vegetarians (daily consumption of

\footnotetext{
Abbreviations: ApoB, apolipoprotein B; MFP, meat, fish and poultry; NHANES III, Third National Health and Nutrition Examination Survey; USDA, US Department of Agriculture

*Corresponding author: Dr Ellen Smit, fax +1 410955 1383, email esmit@jhsph.edu
} 
animal flesh) (Melby et al. 1994). The study showed lower serum cholesterol concentrations among vegetarians, higher concentrations among non-vegetarians, and intermediate concentrations among semi-vegetarians. Saturated fat intake was also lower among the vegetarians and higher among non-vegetarians.

Posner et al. (1993) evaluated the cross-sectional relationship between diet and serum cholesterol level from the Framingham Heart Study cohort that was limited to women. They found serum cholesterol to be inversely associated with intakes of both plant and animal protein. The association was stronger for plant protein. In a longitudinal study of healthy young people (13-27 years old), a positive association was found between animal protein consumption and serum cholesterol (Post et al. 1997). This relationship disappeared after they adjusted for other dietary variables including saturated fat.

Few epidemiological studies have looked at more specific sources of animal and plant proteins. Currently available nutrition analysis systems only compute total protein intake, and do not separate the intake by protein source. This is mainly due to the difficulty in determining type of protein in mixed dishes or combination foods. The number of food items is potentially large and the process to sort out protein type is extensive. While some systems do include an animal and/or plant protein variable, separation by more specific protein types has not been available.

We have reported on specific sources of animal and plant proteins for the total US population and for sub-groups defined by race-ethnicity, age and sex (Smit et al. 1999). The purpose of the present study was to examine the relationship between intake of protein sources and concentrations of blood lipids in a representative sample of the civilian non-institutionalized adult population in the United States.

\section{Methods}

\section{Study population}

The study population consisted of participants in phase 1 of the Third National Health and Nutrition Examination Survey (NHANES III). The study design is described in detail in the Plan and Operation of the Third National Health and Nutrition Examination Survey (National Center for Health Statistics, 1994). Briefly, NHANES III used a highly stratified multistage probability design and employed over-sampling of the elderly, non-Hispanic blacks and Mexican Americans. The survey consisted of two phases of equal length and similar sample size. Unbiased estimates of health and nutrition characteristics can be made for either phase 1 (1988-91) or phase 2 (1991-4).

\section{Dietary intake assessment}

One $24 \mathrm{~h}$ dietary recall was collected from each subject during the visit to the mobile examination centre. Dietary intake may differ by weekday, especially weekend days. To capture intake on all days of the week, the $24 \mathrm{~h}$ recalls were collected on every day of the week. Fridays had a higher proportion of recalls due to operational procedures to improve response rate by allowing a high number of exams on Saturdays.

The dietary interviewers used the dietary data collection system, which is an automated standardized interactive dietary interview and coding system. The system was specifically developed for NHANES III by the University of Minnesota Nutrition Coordinating Center. Participants were asked to report all foods and beverages consumed, excluding plain drinking water, during the previous $24 \mathrm{~h}$, from midnight to midnight. The food database for the dietary data collection system was linked to the US Department of Agriculture's (USDA) survey nutrition database with some foods being added to the database throughout NHANES III.

\section{Protein source determinations}

For foods containing a single ingredient, protein source was assigned. For foods containing more than a single ingredient, one of the following methods was used. Food codes were linked to the USDA survey recipe file and the contribution of each ingredient to total protein was determined. Similarly, ingredients containing more than one ingredient themselves were also broken down into sub-ingredients. For example: a ham sandwich may have the ingredients ham, mayonnaise and bread. Sub-ingredients for mayonnaise and bread were obtained and protein contributions were determined for each sub-ingredient. For foods without an existing USDA recipe, ingredient and recipe information was obtained from manufacturers, USDA, or the Food and Drug Administration; or a formulary was obtained from food product formulation information. For foods where no recipe or formulary could be found, proportions of ingredients were estimated according to the order on the food label ingredient list and their contribution to selected known nutrient values (Schakel et al. 1989; Westrich et al. 1994).

\section{Blood lipid measurements}

Blood lipid concentrations were determined on frozen specimens. Measurements were standardized to meet the Centers for Disease Control and Prevention-National Heart, Lung and Blood Institute Lipid Standardization Program guidelines (Myers et al. 1989). Serum total cholesterol was analysed enzymically in the Johns Hopkins University Lipid Research Clinic Laboratory, using the method of Allain et al. (1974) and the reagent mixture from Boehringer Mannheim Diagnostics (Cholesterol/HP, catalogue no. 816302; Boehringer Mannheim Diagnostics, Indianapolis, IN, USA). HDL-cholesterol was measured in supernatant fractions following precipitation of ApoBcontaining lipoproteins with heparin- $\mathrm{MnCl}_{2}$ and removal of excess Mn by precipitation with $\mathrm{NaHCO}_{3}$. Triacylglycerols were analysed enzymically also using commercially available reagents (A-gent Triacylglycerols Reagent Set; Abbott Laboratories, North Chicago, IL, USA: Triacylglycerols/GPO; Boehringer Mannheim Diagnostics). LDLcholesterol was calculated using the formula of Friedewald et al. (1972) and was limited to those participants having fasted for at least $9 \mathrm{~h}$ (National Cholesterol Education Program, 1993). Since the Friedewald equation is valid 
only for individuals with a serum triacylglycerol value not exceeding $4.516 \mathrm{mmol} / \mathrm{l}$, participants with values exceeding $4.516 \mathrm{mmol} / \mathrm{l}$ were excluded from the LDL analysis. ApoB was measured by three different methods, namely radial immunodiffusion, rate immunonephelometry, and the WHO-International Federation of Clinical Chemistry method (Albers \& Marcovina, 1989; Marcovina et al. 1991; Bachorik et al. 1994). Results using the radial immunodiffusion and rate immunonephelometry methods were adjusted to the WHO-International Federation of Clinical Chemistry method.

\section{Sample size}

A sample of 11656 persons aged 20 years and older was selected and asked to complete an extensive interview and health examination. Of these, 9488 ( $81 \%$ of the sample persons) were interviewed, and 8213 (71\% of the sample persons) were examined. The total sample for the dietary interview, excluding incomplete and unreliable recalls was 7931 adults, which is $97 \%$ of those participants that were examined and $68 \%$ of the total persons sampled. For the purpose of the present study, we excluded those participants who reported having been told they had high blood cholesterol concentrations, since they may have undergone varying degrees of lipid-lowering treatment. Participants with incomplete protein data were also excluded and the final sample size for all adults (aged 20 years and older) was 6228. LDL analysis was limited to those participants who had fasted for at least $9 \mathrm{~h}$ (2719 adults).

\section{Statistical analysis}

Total and adjusted mean dietary intakes were calculated using the Statistical Analysis Systems program (release 6.11, 1996; SAS Institute Inc., Cary, NC, USA). Sample weights, provided by the National Center for Health Statistics, were used to correct for differential selection probabilities and to adjust for non-coverage and non-response. For variance and quantile estimation, the balance repeated replication method in the software package WesVarPC (Brick et al. 1997) was used. Statistical differences in adjusted means were determined by two-sided $t$ tests also using WesVarPC, and $P$ values are reported at levels of $\leq 0.05$ and $\leq 0 \cdot 01$.

\section{Results}

Table 1 shows the demographic characteristics of the sample population, given as weighted and unweighted proportions. We examined mean intakes of dietary variables by quartiles of blood lipids. We ranked our population according to blood lipid concentrations, and created the quartiles by dividing the sample into fourths, each fourth with a similar weighted sample size. Quartile 1 is the fourth of the sample population with the lowest blood lipid concentrations, and quartile 4 is the fourth with the highest blood lipid concentrations. Both the crude and age-, sex-, and race-adjusted values are shown in Table 2 for serum cholesterol and in Table 3 for ApoB.
Table 1. Demographic characteristics for the Third National Health and Nutrition Examination Survey, phase 1 study population ( $n$ 6228)

\begin{tabular}{lcc}
\hline & $\begin{array}{c}\text { Unweighted } \\
\text { values }\end{array}$ & $\begin{array}{c}\text { Weighted } \\
\text { values }\end{array}$ \\
\hline Sex (\%) & 51 & 48 \\
$\quad$ Men & 49 & 52 \\
Women & & \\
Age (\%) & 45 & 53 \\
20-39 years & 26 & 28 \\
$40-59$ years & 29 & 19 \\
60+ years & & \\
Race (\%) & 42 & 76 \\
Non Hispanic white & 26 & 11 \\
Non Hispanic black & 30 & 5 \\
Mexican American & 2 & \\
Other & & 19 \\
Family income (\%) & 28 & 61 \\
Less than \$10 000 & 60 & 20 \\
\$1000-\$4999 & 12 & 26 \\
\$50 000 or more & & 34 \\
Education (\%) & 43 & 40 \\
Less than High School & 29 & \\
High School & 27 & \\
More than High School & &
\end{tabular}

\section{Total serum cholesterol}

The percentages of energy from protein were similar in all quartiles of serum cholesterol (Table 2), while the percentage of energy from carbohydrates was higher in quartile 1 than quartiles 2-4. The animal: plant protein ratio for quartile 1 of serum cholesterol was lower than for the higher quartiles, particularly for quartile 3 . However, this difference did not reach statistical significance after further adjustment for saturated fat (2.9 for quartile $1 ; 3.1$ for quartile 4; results not shown). The percentage of animal protein was lower in quartile 1 than quartiles 3 and 4 . After adjustment for saturated fat, the percentage of animal protein remained lower in quartile $1(66 \cdot 6)$ than quartiles $3(68.8)$ and $4(68.2)$, although this was only significant for quartile 3. The percentage of the combined meat, fish and poultry (MFP) protein was also lower in quartile 1 than quartile 4, while the percentage of beef protein was lower in both quartiles 1 and 2 compared with quartile 4 . The percentage of pork protein in quartile 1 was lower than quartiles 2-4. After adjusting for saturated fat, the differences for MFP, beef and pork protein persisted (results not shown). Although the age-, sex-, and race-adjusted percentages of milk protein were not significantly different for the four quartiles, after additional adjustment for saturated fat, the percentage milk protein in quartile 1 of serum cholesterol was higher than in quartile 4 (12.9 and 11.1 respectively).

The percentage of plant protein in the diets of persons in quartile 1 of serum cholesterol was higher than for quartiles 3 and 4, with intake in quartile 2 being higher than that in quartile 3. After adjusting for saturated fat, the differences persisted, yet this time plant protein was significantly higher only for quartile $1(33.3)$ than quartile 3 (31.2). The percentage of protein from nuts was higher in quartile 1 than quartile 3, again with differences remaining after 
Table 2. Daily dietary intake by quartiles (Q) of serum total cholesterol of adults 20 years of age and older who had never been told that their blood cholesterol was high: United States, $1988-91$ (Mean values with their standard errors, and age-, sex- and race-adjusted mean values)

\begin{tabular}{|c|c|c|c|c|c|c|c|c|c|c|c|c|}
\hline & \multicolumn{8}{|c|}{ Quartile of serum total cholesterol } & & & & \\
\hline & \multicolumn{2}{|c|}{$\begin{array}{c}\mathrm{Q1} \\
\leq 4.29 \mathrm{mmol} / \mathrm{l}\end{array}$} & \multicolumn{2}{|c|}{$\begin{array}{c}\mathrm{Q} 2 \\
4.3-4.98 \mathrm{mmol} / \mathrm{l}\end{array}$} & \multicolumn{2}{|c|}{$\begin{array}{c}\text { Q3 } \\
4.99-5.67 \mathrm{mmol} / \mathrm{l}\end{array}$} & \multicolumn{2}{|c|}{$\begin{array}{c}\mathrm{Q} 4 \\
\geq 5.68 \mathrm{mmol} / \mathrm{l}\end{array}$} & \multicolumn{4}{|c|}{ Adjusted mean } \\
\hline & Mean & SEM & Mean & SEM & Mean & SEM & Mean & SEM & Q1 & Q2 & Q3 & Q4 \\
\hline Total energy (kJ) & 9510 & 247 & 9489 & 205 & 9142 & 172 & 8782 & 192 & 7786 & 8196 & 8088 & 8125 \\
\hline Protein (\% energy) & 14.7 & 0.3 & $15 \cdot 1$ & 0.2 & $15 \cdot 6$ & 0.2 & 15.7 & 0.1 & $16 \cdot 1$ & $16 \cdot 3$ & $16 \cdot 6$ & 16.5 \\
\hline Carbohydrate (\% energy) & $50 \cdot 3$ & 0.8 & 48.5 & 0.4 & 47.8 & 0.4 & $48 \cdot 8$ & 0.3 & $52 \cdot 1$ & $50 \cdot 1^{* *}$ & $49 \cdot 4^{\star *}$ & $50 \cdot 1^{*}$ \\
\hline Fat (\% energy) & 33.4 & 0.5 & 34.3 & 0.3 & 34.4 & 0.5 & $34 \cdot 1$ & 0.2 & 31.6 & $32 \cdot 5^{\star}$ & $32 \cdot 6^{\star}$ & 32.5 \\
\hline MUFA (\% energy) & $12 \cdot 4$ & 0.2 & $12 \cdot 7$ & 0.2 & $12 \cdot 7$ & 0.2 & $12 \cdot 7$ & 0.1 & 11.7 & $12 \cdot 1$ & 12.0 & $12 \cdot 0$ \\
\hline PUFA (\% energy) & 7.0 & 0.2 & $7 \cdot 2$ & 0.1 & $7 \cdot 1$ & 0.2 & $6 \cdot 8$ & 0.1 & 6.9 & 7.0 & 6.8 & $6.5+t$ \\
\hline Saturated fat (\% energy) & 11.4 & 0.2 & 11.7 & 0.1 & $12 \cdot 0$ & 0.2 & 11.9 & 0.1 & 10.4 & $10 \cdot 8$ & $11 \cdot 1^{*}$ & $11 \cdot 2^{\star \star}$ \\
\hline Dietary cholesterol (mg) & 284 & 14 & 302 & 7 & 305 & 12 & 294 & 9 & 271 & $300^{*}$ & $307^{\star}$ & $305^{\star}$ \\
\hline Dietary fibre $(\mathrm{g})$ & $16 \cdot 2$ & 0.4 & $16 \cdot 5$ & 0.3 & $15 \cdot 9$ & 0.4 & 15.5 & 0.3 & 16.5 & $17 \cdot 0$ & $16 \cdot 2$ & $15 \cdot 8+\dagger$ \\
\hline Animal : plant protein & $2 \cdot 7$ & 0.1 & $2 \cdot 8$ & 0.1 & 3.0 & 0.1 & 2.9 & 0.1 & $2 \cdot 7$ & $2 \cdot 8$ & $3 \cdot 1^{*}$ & 3.0 \\
\hline \multicolumn{13}{|l|}{ Protein sources (\%): } \\
\hline Animal & 65.8 & 0.8 & $67 \cdot 0$ & 0.5 & 68.1 & 0.6 & $67 \cdot 2$ & 0.5 & $65 \cdot 3$ & $66 \cdot 8$ & $68 \cdot 2^{* *} \dagger$ & $67 \cdot 7^{* *}$ \\
\hline Meat & 40.7 & 1.1 & 42.3 & 0.8 & 42.9 & 0.8 & 43.1 & 0.5 & 43.2 & 44.8 & 45.5 & $46 \cdot 2^{*}$ \\
\hline Beef & 15.5 & 1.0 & $15 \cdot 2$ & 0.8 & $16 \cdot 6$ & 0.8 & 17.5 & 0.7 & $13 \cdot 8$ & 14.0 & $15 \cdot 6$ & $16 \cdot 9^{*}+\dagger$ \\
\hline Pork & 6.7 & 0.5 & 8.8 & 0.6 & 8.1 & 0.5 & 8.3 & 0.5 & 8.3 & $10 \cdot 5^{\star *}$ & $9 \cdot 8^{\star *}$ & $10 \cdot 1^{\star \star}$ \\
\hline Poultry & 12.6 & 0.9 & $12 \cdot 3$ & 0.8 & $12 \cdot 0$ & 0.5 & 11.7 & 0.5 & 14.2 & 13.7 & 13.5 & $13 \cdot 2$ \\
\hline Fish & 5.4 & 1.0 & $5 \cdot 2$ & 0.8 & 5.5 & 0.7 & $5 \cdot 1$ & 0.6 & 6.4 & 5.9 & $6 \cdot 0$ & 5.4 \\
\hline Egg & 3.9 & 0.3 & $4 . \overline{5}$ & 0.2 & 4.6 & 0.3 & $4 \cdot 3$ & 0.2 & 4.9 & 5.4 & $5 \cdot 3$ & 5.0 \\
\hline Dairy & 21.3 & 0.9 & $20 \cdot 2$ & 0.5 & $20 \cdot 7$ & 0.7 & $19 \cdot 7$ & 0.5 & $17 \cdot 2$ & $16 \cdot 6$ & 17.4 & 16.5 \\
\hline Milk & $12 \cdot 1$ & 0.6 & 11.7 & 0.4 & $12 \cdot 8$ & 0.6 & 12 & 0.5 & 12.2 & 11.6 & $12 \cdot 3$ & 10.9 \\
\hline Cheese & $9 \cdot 2$ & 0.7 & 8.4 & 0.5 & 7.9 & 0.5 & $7 \cdot 8$ & 0.5 & 4.9 & 4.9 & $5 \cdot 1$ & $5 \cdot 7$ \\
\hline Plant & 34.2 & 0.8 & 33.0 & 0.5 & 31.9 & 0.6 & 32.8 & 0.5 & 34.7 & 33.2 & $31.8^{* *} t$ & $32 \cdot 3^{* *}$ \\
\hline Vegetable & 8.3 & 0.4 & 8.2 & 0.3 & 7.8 & 0.2 & 8.0 & 0.2 & 9.0 & 8.8 & 8.5 & 8.6 \\
\hline Fruit & 1.7 & 0.2 & 1.6 & 0.1 & 1.5 & 0.1 & 1.6 & 0.1 & $2 \cdot 2$ & $2 \cdot 0$ & $1 \cdot 8^{\star *}$ & $1 \cdot 7^{\star *}$ \\
\hline Grain & $18 \cdot 8$ & 0.4 & 17.9 & 0.4 & 17.5 & 0.5 & 18.0 & 0.4 & 17.6 & $16 \cdot 7$ & $16 \cdot 2^{*}$ & $16 \cdot 7$ \\
\hline Legumes, soyabeans, nuts and seeds & 4.2 & 0.3 & 4.3 & 0.3 & 3.9 & 0.2 & 3.9 & 0.3 & $5 \cdot 0$ & 5.0 & 4.5 & 4.3 \\
\hline Nuts and seeds & 2.2 & 0.3 & $2 \cdot 1$ & 0.3 & 1.7 & 0.2 & 1.9 & 0.3 & $1 \cdot 7$ & 1.6 & $1.0^{*}$ & 1.2 \\
\hline
\end{tabular}

MUFA, monounsaturated fatty acids; PUFA, polyunsaturated fatty acids.

Mean values were significantly different from those for $Q 1$ : ${ }^{*} P<0.05,{ }^{*} P<0.01$

Mean values were significantly different from those for $\mathrm{Q} 2: \uparrow P<0.05$, $† \dagger P<0.01$. 
Table 3. Daily dietary intake by quartiles (Q) of serum apolipoprotein B of adults 20 years of age and older who had never been told that their blood cholesterol was high: United States, 1988-91 (Mean values with their standard errors, and age-, sex- and race-adjusted mean values)

\begin{tabular}{|c|c|c|c|c|c|c|c|c|c|c|c|c|}
\hline & \multicolumn{8}{|c|}{ Quartile of apolipoprotein B } & & & & \\
\hline & \multicolumn{2}{|c|}{$\begin{array}{c}\mathrm{Q1} \\
\leq 2.07 \mathrm{mmol} / \mathrm{l}\end{array}$} & \multicolumn{2}{|c|}{$\begin{array}{c}\text { Q2 } \\
2.08-2.49 \mathrm{mmol} / \mathrm{l}\end{array}$} & \multicolumn{2}{|c|}{$\begin{array}{c}\mathrm{Q3} \\
2.50-2.95 \mathrm{mmol} / \mathrm{l}\end{array}$} & \multicolumn{2}{|c|}{$\begin{array}{c}\text { Q4 } \\
\geq 2.96 \mathrm{mmol} / \mathrm{l}\end{array}$} & \multicolumn{4}{|c|}{ Adjusted mean } \\
\hline & Mean & SEM & Mean & SEM & Mean & SEM & Mean & SEM & Q1 & Q2 & Q3 & Q4 \\
\hline $\begin{array}{l}\text { Total energy (kJ) } \\
\text { Protein (\% energy) } \\
\text { Carbohydrate (\% energy) } \\
\text { Fat (\% energy) } \\
\text { MUFA (\% energy) } \\
\text { PUFA (\% energy) } \\
\text { Saturated fat (\% energy) } \\
\text { Dietary cholesterol (mg) } \\
\text { Dietary fibre }(\mathrm{g})\end{array}$ & $\begin{array}{c}9171 \\
14.6 \\
49.5 \\
33.2 \\
12.3 \\
7.0 \\
11.3 \\
284 \\
15.9\end{array}$ & $\begin{array}{c}255 \\
0.3 \\
1.0 \\
0.5 \\
0.3 \\
0.2 \\
0.2 \\
11 \\
0.4\end{array}$ & $\begin{array}{c}9485 \\
15 \cdot 2 \\
48 \cdot 4 \\
34 \cdot 1 \\
12 \cdot 6 \\
7.0 \\
11.8 \\
294 \\
16 \cdot 2\end{array}$ & $\begin{array}{c}226 \\
0.2 \\
0.5 \\
0.4 \\
0.2 \\
0.2 \\
0.2 \\
13 \\
0.4\end{array}$ & $\begin{array}{c}9410 \\
15.4 \\
48.5 \\
34.5 \\
12.7 \\
7.0 \\
12.2 \\
306 \\
16.6\end{array}$ & $\begin{array}{c}172 \\
0.2 \\
0.4 \\
0.4 \\
0.2 \\
0.1 \\
0.2 \\
9 \\
0.3\end{array}$ & $\begin{array}{c}8778 \\
15 \cdot 8 \\
49 \cdot 1 \\
34.1 \\
12 \cdot 8 \\
6.8 \\
11 \cdot 8 \\
298 \\
15.4\end{array}$ & $\begin{array}{c}159 \\
0.1 \\
0.4 \\
0.3 \\
0.1 \\
0.1 \\
0.1 \\
10 \\
0.3\end{array}$ & $\begin{array}{r}7837 \\
15 \cdot 9 \\
50 \cdot 7 \\
31.4 \\
11 \cdot 7 \\
6.9 \\
10 \cdot 3 \\
282 \\
16 \cdot 7\end{array}$ & $\begin{array}{c}8339 \\
16 \cdot 4 \\
49 \cdot 8 \\
32 \cdot 3 \\
12 \cdot 0 \\
6 \cdot 8 \\
10 \cdot 9^{\star} \\
297 \\
17 \cdot 0\end{array}$ & $\begin{array}{l}8247 \\
16 \cdot 4 \\
49 \cdot 9 \\
32 \cdot 9^{\star \star} \\
12 \cdot 0 \\
6 \cdot 8 \\
11 \cdot 4^{\star *} \dagger \\
305 \\
16 \cdot 7\end{array}$ & $\begin{array}{c}7912 \dagger \\
16 \cdot 6 \\
50 \cdot 5 \\
32 \cdot 5 \\
12 \cdot 1 \\
6 \cdot 6 \\
11 \cdot 0^{\star} \\
303 \\
15 \cdot 3^{* *}+\dagger \neq \ddagger\end{array}$ \\
\hline Animal : plant protein & $2 \cdot 7$ & 0.1 & $2 \cdot 8$ & 0.1 & 2.9 & 0.1 & 2.9 & 0.1 & 2.8 & $2 \cdot 9$ & 2.9 & 3.0 \\
\hline \multicolumn{13}{|l|}{ Protein source (\%) } \\
\hline Animal & $65 \cdot 8$ & 1.0 & $67 \cdot 3$ & 0.6 & $67 \cdot 6$ & 0.5 & 67.4 & 0.6 & 65.4 & $67 \cdot 2$ & $67 \cdot 7$ & $67 \cdot 8$ \\
\hline Meat & $40 \cdot 9$ & 1.2 & $42 \cdot 0$ & $1 \cdot 1$ & $42 \cdot 1$ & 0.8 & 43.7 & 0.6 & 43.8 & 44.9 & 44.6 & $46 \cdot 6^{*} \ddagger$ \\
\hline Beef & $14 \cdot 3$ & 1.0 & $16 \cdot 3$ & 0.8 & $15 \cdot 5$ & 0.7 & $18 \cdot 1$ & 0.8 & $13 \cdot 3$ & $15 \cdot 4$ & $14 \cdot 4$ & $17 \cdot 3^{* *} \ddagger \ddagger$ \\
\hline Pork & 7.1 & 0.5 & 8.2 & 0.6 & 8.7 & 0.4 & 8.2 & 0.6 & 8.7 & 9.9 & $10 \cdot 3^{* *}$ & $9.9^{*}$ \\
\hline Poultry & 12.5 & 1.0 & $12 \cdot 6$ & 0.7 & 11.8 & 0.5 & 11.6 & 0.5 & 13.9 & 13.9 & 13.4 & $13 \cdot 3$ \\
\hline Fish & $6 \cdot 4$ & 1.4 & 4.5 & 0.7 & $5 \cdot 3$ & 0.5 & $5 \cdot 2$ & 0.6 & $7 \cdot 2$ & 5.2 & $5 \cdot 8$ & 5.5 \\
\hline Egg & 4.5 & 0.4 & 4.0 & 0.2 & 4.5 & 0.3 & 4.5 & 0.2 & 5.4 & 4.8 & $5 \cdot 3$ & 5.1 \\
\hline Dairy & $20 \cdot 4$ & 0.9 & 21.3 & 0.7 & $21 \cdot 0$ & 0.7 & $19 \cdot 2$ & 0.5 & $16 \cdot 3$ & 17.5 & $17 \cdot 8$ & $16 \cdot 0 \neq$ \\
\hline Milk & 11.4 & 0.6 & 12.4 & 0.6 & 12.5 & 0.5 & $12 \cdot 1$ & 0.5 & 11.4 & $12 \cdot 1$ & $12 \cdot 1$ & 11.1 \\
\hline Cheese & 9.0 & 0.7 & 8.9 & 0.7 & 8.4 & 0.4 & 7.0 & 0.3 & 4.9 & $5 \cdot 4$ & 5.7 & 4.9 \\
\hline Plant & $34 \cdot 2$ & 1.0 & $32 \cdot 7$ & 0.6 & $32 \cdot 4$ & 0.5 & 32.6 & 0.6 & 34.6 & $32 \cdot 8$ & $32 \cdot 3$ & $32 \cdot 2$ \\
\hline Vegetables & $8 . \overline{3}$ & 0.5 & 8.0 & 0.2 & 8.0 & 0.2 & 8.1 & 0.2 & 8.9 & $8 \cdot 6$ & 8.6 & 8.7 \\
\hline Fruit & 1.7 & 0.2 & 1.6 & 0.1 & 1.5 & 0.1 & 1.5 & 0.1 & 2.2 & $2 \cdot 0$ & $1 \cdot 8^{\star}$ & $1 \cdot 7^{* *}+\dagger$ \\
\hline Grain & $19 \cdot 1$ & 0.5 & $17 \cdot 7$ & 0.5 & 17.9 & 0.4 & $17 \cdot 7$ & 0.4 & 17.9 & $16 \cdot 5$ & $16 \cdot 6$ & $16 \cdot 4^{*}$ \\
\hline Legumes, soyabeans, nuts and seeds & 4.0 & 0.4 & 4.2 & 0.3 & 3.9 & 0.2 & $4 \cdot 1$ & 0.3 & 4.7 & 4.9 & 4.4 & 4.6 \\
\hline Nuts and seeds & $2 \cdot 1$ & 0.3 & $2 \cdot 2$ & 0.3 & 1.8 & 0.2 & 1.8 & 0.2 & 1.6 & 1.6 & 1.3 & 1.2 \\
\hline
\end{tabular}

MUFA, monounsaturated fatty acids; PUFA, polyunsaturated fatty acids.

Mean values were significantly different from those for Q1: ${ }^{*} P<0.05$, ${ }^{*} P<0.01$.

nt from those for $\mathrm{Q} 2: \dagger P<0.05,+\uparrow P<0.01$

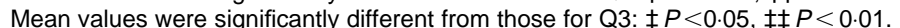


adjusting for saturated fat. The percentage of grain protein was higher in quartile 1 compared with quartile 3 , however, this difference did not reach statistical significance after adjusting for saturated fat (16.8 for quartile 1 ; 16.0 for quartile 3 ). The percentage of fruit protein was higher in quartile 1 than quartiles 3 and 4, regardless of saturated fat adjustment. Since we found the percentage of energy from carbohydrate also to be higher in the lowest quartile than the higher quartiles for serum cholesterol, we adjusted the percentage of fruit protein for percentage of energy from carbohydrate and found that the difference in fruit protein between quartiles 1 and 4 persisted. We also adjusted the percentage of all protein sources for recall day, BMI, smoking, and income and found that the significant differences remained (results not shown).

Fig. 1 shows the percentage relative difference between the reference quartile 1 and quartiles 2, 3 and 4 of serum total cholesterol for selected protein sources. While the absolute difference between the percentage beef protein in quartiles 1 and 4 was $3.1 \%$ (Table 2 ), proportionally this reflects a $22 \%$ difference between these quartiles. Similarly, pork protein was $22 \%$ higher in quartile 4 relative to quartile 1 , while fruit protein was $23 \%$ lower in quartile 4 relative to quartile 1 .

\section{Apolipoprotein B}

The percentages of MFP and beef protein in quartile 4 were higher than in quartiles $1-3$ (Table 3 ), although this did not reach statistical significance for quartile 2 . These differences remained after adjusting for saturated fat. The percentage of pork protein was lower in quartile 1 than quartiles 3 and 4, and not significantly lower than quartile 2. After adjusting for saturated fat intake, the difference remained significant for quartiles $1(9.1 \%)$ and $3(10.3 \%)$, but not for quartile $4(10 \cdot 1 \%)$ of ApoB. The percentage of dairy protein was higher in quartile 3 than in quartile 1, yet quartiles 1 and 4 were similar. After adjusting for saturated fat, quartile $4(16.8 \%)$ was lower than quartile $2(18.4 \%)$ and, although not significantly, was also lower than quartiles $1(18.0 \%)$ and $3(18.1 \%)$. The percentage of grain protein for quartile 1 was higher than for quartile 4 , while this difference did not reach statistical significance after adjusting for saturated fat. The percentage of fruit protein was higher in quartile 1 than quartiles 3 and 4, with quartile 2 being higher than quartile 4 . After adjusting for saturated fat, the percentage of fruit protein in quartile 4 remained lower than both quartiles 1 and 2 of ApoB. Again, we adjusted the percentages of all protein sources for recall day, BMI, smoking, and income and found that the significant differences persisted (results not shown).

Fig. 2 shows the percentage relative difference between the reference quartile 1 and quartiles 2, 3 and 4 of serum total cholesterol for selected protein sources. While the absolute difference between the percentage beef protein in quartiles 1 and 4 was $4 \%$ (Table 3 ), proportionally this reflects a $30 \%$ difference between these quartiles. Similarly, pork protein was $14 \%$ higher in quartile 4 relative to quartile 1, while grain protein was $8 \%$ lower and fruit protein $23 \%$ lower in quartile 4 relative to quartile 1 .

\section{Lipoproteins}

Our analysis for quartiles of LDL showed that the differences in protein sources between the quartiles were similar to those for serum cholesterol, yet none reached statistical significance (results not shown). The lack of statistical significance may have been due to a loss in power as a result of the smaller sample size for LDL ( $n$ 2719). We did observe a higher percentage of energy from protein for quartile 4 (LDL $\geq$ $3.78 \mathrm{mmol} / \mathrm{l})$ compared with quartile 1 (LDL $\leq 2.53 \mathrm{mmol} / \mathrm{l})$, 16.9 and $16.3 \%$ respectively. We also observed a lower

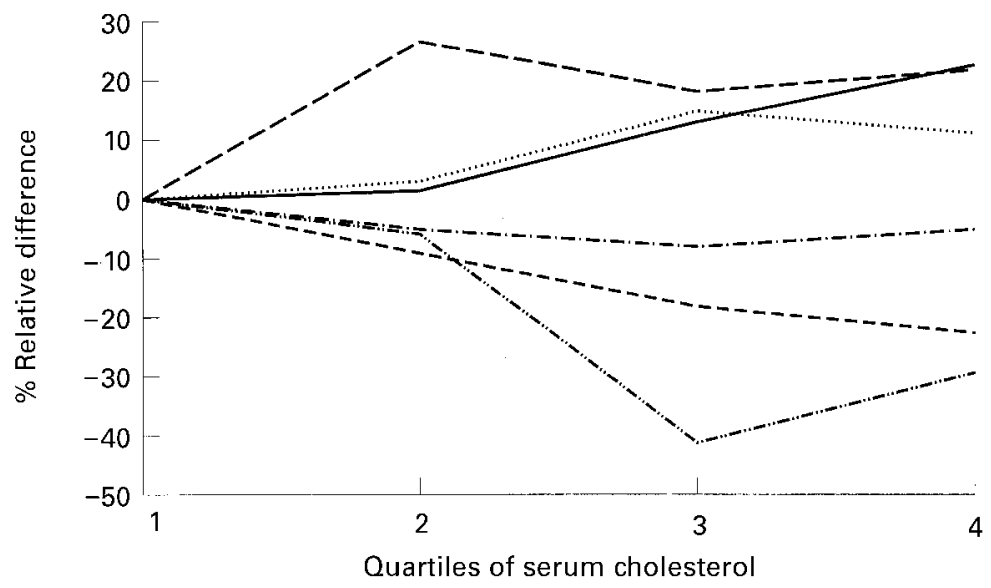

Fig. 1. Percentage relative difference between the reference quartile 1 and quartiles 2, 3 and 4 of serum cholesterol for selected protein sources: $(-)$, beef; (- - -), pork; (......), animal : plant protein; (-.-.), grain; (---), fruit; (-..-..), nuts. Values are age-, sex- and race-adjusted mean values for the phase 1 study population from the Third National Health and Nutrition Examination Survey (see Table 1). Serum cholesterol levels for the quartiles were: quartile 1 , $\leq 4.29 \mathrm{mmol} / /$; quartile $2,4.3-4.98 \mathrm{mmol} / /$; quartile $3,4.99-5.67 \mathrm{mmol} / /$; quartile 4 , $\geq 5.68 \mathrm{mmol} / \mathrm{l}$. 


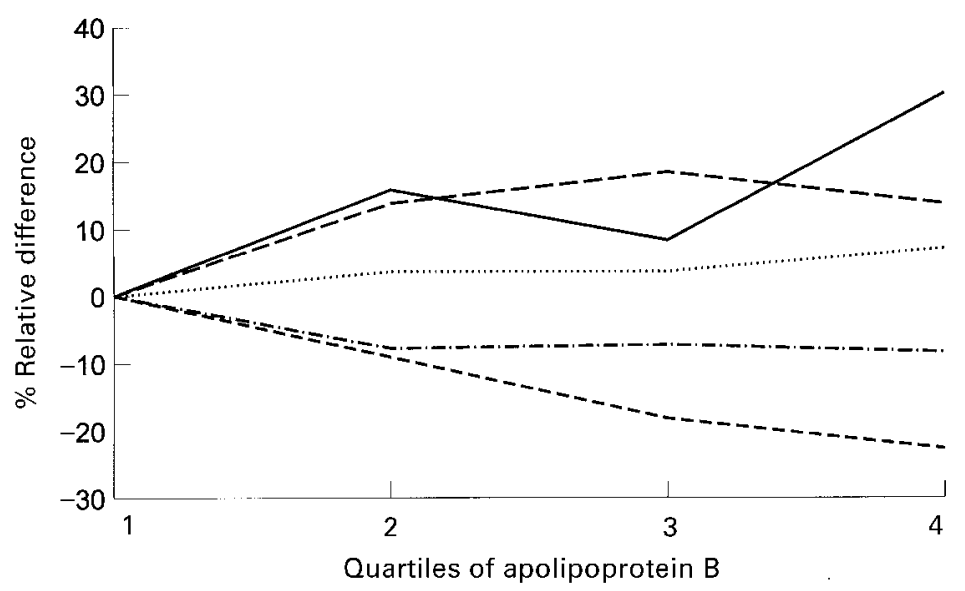

Fig. 2. Percentage relative difference between the reference quartile 1 and quartiles 2, 3 and 4 of apolipoprotein B concentration for selected protein sources: $(-)$, beef; $(---)$, pork; $(\cdot \cdots \cdots)$, animal : plant protein; (-.-.), grain; $(--)$, fruit. Values are age-, sex- and race-adjusted mean values for the phase 1 study population from the Third National Health and Nutrition Examination Survey (see Table 1). Apolipoprotein B levels for the quartiles were: quartile 1 , $\leq 2.07 \mathrm{mmol} / /$; quartile 2, $2.08-2.49 \mathrm{mmol} / /$; quartile $3,2.50-2.95 \mathrm{mmol} / \mathrm{l}$; quartile $4, \geq 2.96 \mathrm{mmol} / \mathrm{l}$.

percentage of energy from total fat in quartile $1(31 \cdot 7)$ than in quartile 4 (33.1). Similarly, we found a higher percentage of saturated fat in quartiles $3(11.2)$ and 4 (11.5) compared with quartile $1(10 \cdot 5)$ of LDL.

We analysed dietary intake according to quartiles of HDL and found that total energy intake was higher in quartile 4 of $\mathrm{HDL}(\mathrm{HDL} \geq 1.55 \mathrm{mmol} / \mathrm{l})$ than in quartiles 1 (HDL $\leq 1.06 \mathrm{mmol} / \mathrm{l}$ ) to 3 (HDL $1.29-1.54 \mathrm{mmol} / \mathrm{l}$ ) (7878, 8042, 7887, 8460 kJ, quartiles 1-4 respectively). The percentages of energy from protein, total fat, saturated, polyunsaturated and monounsaturated fat were similar for all quartiles of HDL. The percentage of energy from carbohydrate, however, was lower in quartile 4 than quartiles 1-3 (52, 51, 50, 48; quartiles 1-4 respectively). For the protein sources, the percentage of cheese protein in quartile 4 (6.2) was higher than in quartiles $1(5.0)$ and $2(4.8)$ for HDL. The percentage of fruit protein was lower in quartile 1 $(1.7)$ than quartile $4(2 \cdot 0)$. Differences remained after adjustments for recall day, BMI, smoking, income, physical activity and alcohol intake (results not shown).

\section{Discussion}

We found that in this nationally representative sample of US adults who had never been told they had high blood cholesterol, the percentages of animal protein intake, especially beef and pork protein, were higher among persons with higher serum cholesterol concentrations than among those in the lower quartiles of serum cholesterol (see Figs. 1 and 2). In contrast, consumption of plant protein, including nut, grain, and fruit protein, was higher among persons with the lower concentrations of serum cholesterol than among persons with higher concentrations of serum cholesterol.

Very few epidemiological studies have looked at animal and plant protein, even fewer have looked at specific protein sources. Our results, however, agree with those of Post et al.
(1997) who found a positive correlation between serum cholesterol and animal protein intake. Campbell et al. (1990) and Campbell \& Chen (1994), in a cross-sectional survey in China, also found positive associations of serum cholesterol and ApoB with meat and animal protein, and a negative association with plant protein. Likewise, our results agree with those of Posner et al. (1993) who found an inverse association between serum cholesterol and plant protein intake. In contrast, they also found an inverse association with animal protein intake, although the association for plant protein was stronger. This contrasting finding may, in part, be due to differences in protein source determinations, since protein sources were not broken down into specific animal and plant proteins. For example, our results showed stronger differences for the specific beef protein than for animal proteins combined.

The percentage of milk protein was not significantly different among quartiles of serum cholesterol. After adjusting for saturated fat intake, the percentage of milk protein in quartile 4 was lower than in quartile 1 . This finding is somewhat surprising, because clinical studies have shown casein, a milk protein, to be hypercholesterolaemic (Sirtori et al. 1977; Jacques et al. 1992; Potter et al. 1993; Bakhit et al. 1994; Anderson et al. 1995; Jenkins et al. 1997). The difference observed between our cross-sectional sample and controlled clinical studies may be that casein is usually either the only source of dietary protein or a large proportion of the total protein in clinical studies. In contrast, the milk protein in our study was a smaller proportion of the total protein intake.

The most studied plant protein in relation to blood lipids in clinical studies has been soyabean protein. However, the total soyabean consumption in the US is very low and inferences between soyabean protein intake and blood lipids may not be appropriate in the present study. Mean intake in our sample was only 0.5 (SE 0.04$) \%$ of the total 
protein, and we found no differences among quartiles of blood lipids (results not shown).

Total and saturated fat intakes and protein sources are correlated, and separating the effects of protein sources and fat is difficult. In an attempt to evaluate the impact of saturated fat intake on the observed differences, we adjusted the mean protein sources for the percentage of energy from saturated fat. We also adjusted for total fat, dietary cholesterol and fibre and found that the differences observed for MFP, pork, beef, and fruit protein remained significant (results not shown). However, adjustment may not allow for the determination of separate effects when variables are strongly collinear (McGee et al. 1984; Reed et al. 1985; Clayton \& Hills, 1993). The most robust evidence for the separate effects of protein and fat is best accomplished through controlled metabolic feeding studies. Although epidemiological studies may not be able to show independent effects, from a public health perspective, nutrition is multifactorial. What we eat is a combination of various related intakes. Exchanging animal-based foods with plantbased foods could simultaneously reduce saturated fat intake, increase plant protein, increase grains and fibre, and increase fruit and vegetable consumption.

Using cross-sectional studies to examine disease relationships is not always ideal. They can, however, be very useful in examining intake patterns among quartiles of blood lipids. The $24 \mathrm{~h}$ recall may also not reflect usual or individual intake, but it can provide reasonable group estimates (Karvetti \& Knuts, 1985). The protein source determinations depend heavily on nutrient and recipe databases. The food marketplace is constantly changing and only limited information is available about formulations of brand-name products. Despite these limitations, we consider that our data provide reasonable estimates of protein sources for the quartiles of blood lipids.

We observed the lower percentages of MFP, beef and pork protein consistently with lower total serum cholesterol and ApoB concentrations among those adults who had never been told they had high blood cholesterol. We also observed a higher percentage of fruit protein consistently with lower total serum cholesterol and ApoB levels. We cannot derive from these data any cause-and-effect relationship, nor can we rule out that protein sources may be indicators of another dietary component. The study does provide support for the importance of assessing intake of specific protein sources, especially in studies that address dietary intake in relation to blood lipids.

\section{Acknowledgements}

This study was supported in part by an NIH doctoral cardiovascular epidemiology training grant (5T32HL07024-20) and a JHU summer epidemiology programme grant.

\section{References}

Albers JJ \& Marcovina SM (1989) Standardization of apolipoprotein B and A1 measurements. Clinical Chemistry 35, 13571361.

Allain CC, Poon LS, Chan CSG, Richmond W \& Fu PC (1974) Enzymatic determinations of total serum cholesterol. Clinical Chemistry 20, 470-475.
Anderson JW, Johnstone BM \& Cook-Newell ME (1995) Metaanalysis of the effects of soy protein intake on serum lipids. New England Journal of Medicine 333, 276-282.

Bachorik PS, Lovejoy KL, Carroll MD, Johnson CL, Albers JJ \& Marcovina SM (1994) Measurement of apolipoproteins A-1 and B during the National Health and Nutrition Examination Survey (NHANES III). Clinical Chemistry 40, 1915-1920.

Bakhit RM, Klein BP, Essex-Sorlie D, Ham JO, Erdman JW \& Potter SM (1994) Intake of $25 \mathrm{~g}$ of soybean protein fiber alters plasma lipids in men with elevated cholesterol concentrations. Journal of Nutrition 124, 213-222.

Beynen AC \& West CE (1987) Cholesterol metabolism in swine fed diets containing either casein or soybean protein. Journal of the American Oil Chemists' Society 64, 1178-1182.

Brick JM, Broene P, James P \& Severynse J (1997) A User's Guide to WesVarPC. Rockville, MD: Westat Inc.

Campbell TC \& Chen J (1994) Diet and chronic degenerative diseases: perspectives from China. American Journal of Clinical Nutrition 59, 1153S-1161S.

Campbell TC, Chen J, Liu C, Li J \& Parpia B (1990) Nonassociation of aflatoxin with primary liver cancer in a cross-sectional ecological survey in the People's Republic of China. Cancer Research 50, 6882-6893.

Carroll KK (1978) Dietary protein in relation to plasma cholesterol levels and atherosclerosis. Nutrition Reviews 36, 1-5.

Clayton D \& Hills M (1993) Statistical Models in Epidemiology. New York, NY: Oxford University Press.

Conner WE \& Conner SL (1972) The key role of nutritional factors in the prevention of coronary heart disease. Preventive Medicine 1, 49-83.

Friedewald WT, Levy RI \& Fredrickson DS (1972) Estimation of the concentration of low density lipoprotein cholesterol in plasma without the use of the preparative ultracentrifuge. Clinical Chemistry 18, 499-502.

Ignatowski A (1908) Influence de la nourriture animale sur l'organisme des lapins (Influence of animal foods on the rabbit organism). Archives Medecine Experimentale Anatomie Pathologiques 20, 1-20.

Jacques H, Laurin D, Moorjani S, Steinke FH, Gagne C, Brun D \& Lupien PJ (1992) Influence of diets containing cow's milk or soy protein beverage on plasma lipids in children with familial hypercholesterolemia. Journal of the American College of Nutrition 11, Suppl., 69S-73S.

Jenkins DJ, Popvich DG, Kendall CW, Vidgen E, Tariq N, Ransom TP, Wolever TM, Vuksan V, Mehling CC, Boctor DL, Bolognesi C, Huang J \& Patten R (1997) Effect of a diet high in vegetables, fruit, and nuts on serum lipids. Metabolism: Clinical and Experimental 45, 530-537.

Karvetti RL \& Knuts LR (1985) Validity of the 24-hour dietary recall. Journal of the American Dietetic Association 85, 1437-1442.

Kritchevsky D, Tepper SA \& Klurfeld DM (1987) Dietary protein and atherosclerosis. Journal of the American Oil Chemists' Society 64, 1167-1171.

McGee D, Reed D \& Yano K (1984) The results of logistic analyses when variables are highly correlated: an empirical example using diet and CHD incidence. Journal of Chronic Disease 39, 713-719.

Marcovina SM, Albers JJ, Dati F, Ledue TB \& Richie RF (1991) International Federation of Clinical Chemistry standardization project for measurements of apolipoprotein a1 and b. Clinical Chemistry 37, 1676-1682.

Meeker DR \& Kesten HD (1940) Experimental atherosclerosis and high protein diets. Proceedings of the Society for Experimental Biology and Medicine 45, 543-545.

Meeker DR \& Kesten HD (1941) Effect of high protein diets on experimental atherosclerosis of rabbits. Archives of Pathology 31, 147-162. 
Melby CL, Toohey ML \& Cebrick J (1994) Blood pressure and blood lipids among vegetarian, semivegetarian, and nonvegetarian African Americans. American Journal of Clinical Nutrition 59, 103-109.

Myers GL, Cooper GR, Winn CL \& Smith SJ (1989) The Center for Disease Control-National Heart, Lung and Blood Institute Cholesterol Standardization Program. Clinical Laboratory Medicine 9, 105-135.

National Center for Health Statistics (1994) Plan and Operation of the Third National Health and Nutrition Examination Survey, 1988-1994. Vital and Health Statistics, series 1, no. 32. Hyattsville, MD: Public Health Service.

National Cholesterol Education Program (1993) Second Report of the Expert Panel on Detection, Evaluation, and Treatment of High Blood Cholesterol in Adults (Adult Treatment Panel II). Bethesda, MD: National Heart, Lung and Blood Institute, National Institutes of Health.

Posner BM, Cupples LA, Miller DR, Cobb JL, Lutz KJ \& D'Agostino RB (1993) Diet, menopause, and serum cholesterol levels in women: the Framingham Study. American Heart Journal 25, 483-489.

Post GB, Kemper HC, Twisk J \& van Mechelen W (1997) The association between dietary patterns and cardiovascular disease risk indicators in healthy youngsters: results covering fifteen years of longitudinal development. European Journal of Clinical Nutrition 51, 387-393.

Potter SM, Bahkit RM, Essex-Sorlie DL, Weingartner KE, Chapman
KM, Nelson RA, Prabhudesai M, Savage WD, Nelson AI, Winter LW \& Erdman JW (1993) Depression of plasma cholesterol in men by consumption of baked products containing soy protein. American Journal of Clinical Nutrition 58, 501506.

Reed D, McGee D, Yano K \& Hankin J (1985) Diet, blood pressure and multicollinearity. Hypertension 7, 405-410.

Schakel SF, Warren RA \& Buzzard IM (1989) Imputing nutrient values from manufacturers' data. In Proceedings of the 14th National Nutrient Databank Conference, pp. 155-158. Ithaca, NY: CBORD Group Inc.

Sirtori CR, Agradi E, Conti F, Mantero O \& Gatti E (1977) Soybean-protein diet in the treatment of type-II hyperlipoproteinaemia. Lancet 1, 275-277.

Smit E, Nieto FJ, Crespo CJ \& Mitchell P (1999) Estimates of animal and plant protein intake in US adults: results from the Third National Health and Nutrition Examination Survey, 1988-1991. Journal of the American Dietetic Association 99, 813-820.

Snowdon DA (1988) Animal product consumption and mortality because of all causes combined, coronary heart disease, stroke, diabetes, and cancer in Seventh-day Adventists. American Journal of Clinical Nutrition 48, 739-749.

Westrich BJ, Buzzard JM, Gatewood LC \& McGovern PG (1994) Accuracy and efficiency of estimating nutrient values in commercial food products using mathematical optimization. Journal of Food Composition and Analysis 7, 223-239. 